\title{
Tingkat Adopsi Inovasi Pengelolaan Tanaman Terpadu (PTT) Padi Sawah di Kecamatan Leuwiliang, Kabupaten Bogor
}

\section{Rate of Adoption Innovation Integrated Crop Management (ICM) of Paddy in Leuwiliang Sub District, Bogor Discrict}

\author{
Ismilaili $^{1}$, Ninuk Purnaningsih ${ }^{2}$, Pang S. Asngari ${ }^{2}$ \\ ${ }^{1}$ Sekolah Tinggi Penyuluhan Pertanian, Aceh \\ ${ }^{2}$ Departemen Sains Komunikasi dan Pengembangan Masyarakat, \\ Fakultas Ekologi Manusia, Institut Pertanian Bogor, Bogor
}

\begin{abstract}
Integrated crop management (ICM) can increase productivity, economic benefit rice farming through the efficient use of inputs, and conserve land resources for sustainable production systems. The purpose of this study is to analyze the degree of adoption, perception of ICM, and factors that influence the adoption of innovation ICM of paddy in Leuwiliang District. The research location was in Barengkok village and Leuwimekar village, Leuwiliang Sub-district. Research was implemented from May until July 2014. Respondents in this study were 80 farmers. The respondent covered 40 farmers from the Barengkok village and 40 farmers from Leuwimekar village. The data was collected by using a questionnaire and in-depth interviews. Multiple regression analysis test was used to analyze the data. The research results showed (1) The adoption level of integrated crop management (ICM) of paddy in the Leuwiliang Sub district was in high category, and (2) The factors of age, experience, land area, the availability of technology information, knowledge and perceptions of farmers were significantly affected the adoption level of ICM paddy.
\end{abstract}

Keywords: adoptiom, nnovation, paddy field in Leuwiliang, integrated crop management

\begin{abstract}
Abstrak
Penelitian bertujuan untuk menganalisis tingkat adopsi dan menganalisis faktor-faktor yang mempengaruhi adopsi inovasi PTT padi sawah di Kecamatan Leuwiliang Kabupaten Bogor. Lokasi penelitian adalah di Desa Barengkok dan Desa Leuwimekar, Kecamatan Leuwiliang Kabupaten Bogor yang dilaksanakan pada bulan Mei sampai bulan Juli tahun 2014. Jumlah responden penelitian adalah 80 petani, ditetapkan dengan acak proposional meliputi 40 petani dari Desa Barengkok dan 40 petani dari Desa Leuwimekar. Pengumpulan data dilakukan dengan menggunakan kuesioner dan wawancara langsung dengan petani padi. Analisis data menggunakan analisis regresi berganda. Hasil penelitian menunjukkan bahwa (1) Tingkat adopsi inovasi Pengelolaan Tanaman Terpadu (PTT) padi sawah di Kecamatan Leuwiliang, Kabupaten Bogor termasuk kategori tinggi (2) Persepsi petani terhadap komponen teknologi inovasi PTT padi tergolong Sangat Tinggi dan (3) Faktor umur, pengalaman berusahatani, penguasaan lahan, ketersediaan informasi teknologi PTT, pengetahuan dan persepsi petani terhadap inovasi PTT berpengaruh nyata terhadap tingkat adopsi inovasi PTT padi.
\end{abstract}

Kata Kunci: adopsi, inovasi, area persawahan di Leuwiliang, ICM

\section{Pendahuluan}

Komoditas pangan terpenting dalam di Indonesia saat ini adalah beras. Hampir seluruh masyarakat Indonesia saat ini menjadikan beras sebagai makanan pokok sehari-hari, sehingga tuntutan akan pening-katan produksi beras ini menjadi sangat tinggi, sehingga wajar jika saat ini kementrian pertanian selaku stakeholder bidang pertanian berusaha meningkatkan produksi beras guna memenuhi kebutuhan rutin masyarakat tersebut (Balai Pengkajian Teknologi Pertanian, 2012).
Salah satu syarat untuk bisa maju dan berkembang sebuah usaha adalah inovasi yang terus menerus atau berkelanjutan. Penelitian Haryani (2009), salah satu cara peningkatan pendapatan petani adalah melalui teknologi inovasi pada Pengelolaan Tanaman Terpadu (PTT) pada padi sawah, sehingga dengan adanya inovasi PTT diharapkan dapat meningkatkan produksi dan pendapatan petani dengan tidak merusak lingkungan karena inovasi PTT adalah suatu inovasi yang ramah lingkungan.

Pengelolaan Tanaman Terpadu (PTT) adalah suatu pendekatan inovatif dalam upaya

\footnotetext{
${ }^{1}$ Korespondensi penulis

E-mail: ismilailiyahya@yahoo.com
} 
peningkatan efisiensi usahatani padi sawah dengan menggabungkan berbagai komponen teknologi yang saling menunjang dan dengan memperhatikan penggunaan sumber daya alam secara bijak agar memberikan pengaruh yang lebih baik terhadap pertumbuhan dan produktivitas tanaman (Dinas Pertanian Jabar, 2013). Sejak tahun 2001, PTT telah diujicobakan pada lahan petani dengan melibatkan petani setempat di Provinsi Sumatera Utara, Sumatera Barat, Jawa Barat, Jawa Tengah, Jawa Timur, Bali, Nusa Tenggara Barat, dan Sulawesi Selatan. Hasil ujicoba tersebut menunjukkan bahwa inovasi teknologi PTT meningkatkan hasil padi sebesar 7-38\%. Dengan demikian PTT mempunyai prospek yang baik untuk dikembangkan lebih lanjut (Balai Penelitian Tanaman Padi, 2003).

Pusat penelitian pengembangan Tanaman Pangan dan Balai Besar Penelitian Tanaman Padi (BB Padi) telah menghasilkan inovasi Pengelolaan Tanaman Terpadu. Pengujian di Kabupaten Bogor pada tahun tahun 2008 menunjukkan bahwa penerapan PTT di lahan sawah meningkatkan hasil panen rata-rata $19 \%$ dan pendapatan petani ratarata $15 \%$. Data ini menunjukkan bahwa penerapan PTT dapat diandalkan dalam upaya mengatasi kemandegan produksi padi dan meningkatkan pendapatan petani.Wilayah Kecamatan Leuwiliang secara geografis berupa pegunungan dengan alokasi pemanfaatan lahan untuk pemukiman, sawah, tegalan, ladang, perkebunan, dan juga hutan. Perekenomian sekitar Kecamatan Leuwiliang tergolong cukup maju dan juga kegiatan perekonomian paling dominan adalah di sektor perdagangan dan pertanian. Hal ini dikarenakan mayoritas masyarakat Kecamatan Leuwiliang bermatapencaharian utama yakni sebagai petani dan sekaligus merangkap sebagai pedagang kecil untuk meningkatkan penghasilan dan pendapatan mereka. Pada tahun 2013 adopsi komponen teknologi PTT (varietas unggul, sistem tanam, bahan organik, pengairan berselang, pengendalian gulma, hama penyakit, serta penanganan panen dan pascapanen) di Kecamatan Leuwiliang sudah cukup baik. Varietas yang digunakan petani adalah Ciherang, IR super, Inpari, Cibogo, Hibrida dan Mekongga dengan sistem tanam jajar Legowo 2:1 (40 cm x $20 \mathrm{~cm} \times 10$ $\mathrm{cm})$ dan menggunakan bahan organik yang terdiri dari pupuk kompos dan bokhasi. Hasil produktivitas tanaman padi melalui teknologi inovasi PTT di
Kecamatan Leuwiliang terdapat peningkatan hasil produktivitas dari tahun 2009 sampai 2013 yaitu sekitar 2 ton/ha. Pada tahun 2009 hasil produktivitas padi PTT sekitar 6,5 ton/ha dan pada tahun 2013 meningkat sebesar 8,6 ton/ha.

Lahan, menurut Soekartawi (1988), merupakan modal utama dalam melaksanakan kegiatan usaha tani, sebagai aset petani dalam menghasilkan produksi dan sekaligus sumber pendapatan petani. Kecamatan Leuwiliang memiliki luas areal lahan pertanian cukup luas yaitu ratarata seluas 28,4 $\mathrm{Ha}$, dan kebutuhan benih lebih tinggi jika dibandingkan dengan kecamatan lainnya di Kabupaten Bogor. Hal ini melatarbelakangi pentingnya penelitian tentang tingkat adopsi inovasi PTT oleh petani di Kecamatan Leuwiliang, Kabupaten Bogor. Konsep Litterer (Asngari, 1984) digunakan untuk mengukur dan menganalisis persepsi petani. Berdasarkan hal tersebut, maka penelitian ini bertujuan untuk: (1) menganalisis tingkat adopsi inovasi PTT padi sawah di Kecamatan Leuwiliang Kabupaten Bogor, (2) menganalisis persepsi petani terhadap inovasi PTT pada padi, serta (3) menganalisis faktor-faktor disekitar yang mempengaruhi adopsi inovasi PTT padi di Kecamatan Leuwiliang Kabupaten Bogor.

\section{Metode Penelitian}

Penelitian menggunakan metode survei dengan pendekatan explanatory research. Penelitian lapang dilaksanakan di Kecamatan Leuwiliang, Kabupaten Bogor dari bulan Mei 2014 sampai dengan bulan Juli 2014. Teknik pengumpulan data primer dilakukan dengan cara observasi, pengisian kuesioner dan wawancara. Populasi penelitian adalah petani PTT padi yang ada di dua desa di Kecamatan Leuwiliang yaitu Desa Barengkok dan Desa Leuwimekar sebanyak 631 orang petani, dan sampel yang diambil sebanyak 80 orang petani dengan teknik proportional simple random sampling. Jenis data dalam penelitian ini terdiri atas data primer yang diperoleh dari wawancara dengan kuesioner yang berupa pernyataan tentang karakteristik internal, karakteristik eksternal, pengetahuan dan juga persepsi responden terhadap inovasi PTT serta sudah diuji reliabilitas dan validitasnya, dan data sekunder diperoleh dari instansi terkait seperti Badan Pusat Statistik (BPS), Badan Ketahanan Pangan 
dan Pelaksana Penyuluhan Pertanian, Perikanan, Kehutanan (BKP5K), profil kelompok, monografi desa. Analisis data primer dilakukan secara kualitatif dan kuantitatif. Analisis kuantitatif dilakukan secara statistik deskriptif dan inferensial. Statistik deskriptif menggunakan distribusi frekuensi sedangkan data statistik inferensial menggunakan analisis regresi berganda.

\section{Hasil dan Pembahasan}

\section{Karakteristik Internal Petani}

Karakteristik internal petani meliputi umur, pendidikan formal, pendidikan non formal, pengalaman berusaha tani, dan penguasaan lahan. Umur rata-rata petani responden padi di Kecamatan Leuwiliang adalah 50 tahun, dengan variasi mulai dari 25 tahun sampai dengan 73 tahun. Sebagian besar atau 47,5\% dari responden masuk dalam kategori usia tua (50-73 tahun). Berdasarkan penggolongan umur BPS, sebagian besar petani respoden tergolong dalam usia produktif yaitu antara 15 tahun sampai dengan 64 tahun. Petani yang berusia produktif memiliki kemampuan bekerja dan berfikir yang lebih tinggi dibanding dengan tidak produktif. Hal ini menunjukkan bahwa semakin matang usia seseorang maka semakin mudah dalam menerima suatu inovasi baru yang bertujuan untuk mengembangkan usahataninya kearah yang lebih baik dari sebelumnya.

Sebesar 53,75\% tingkat pendidikan formal berada pada kategori rendah (tidak sekolah-Sekolah Dasar), sebanyak 36 petani yang ditempuh selama 6 tahun (SD) dan terdapat 5 petani yang tidak tamat sekolah dasar yaitu hanya menempuh pendidikan kurang

Tabel 1 Karakteristik Internal Petani di Kecamatan Leuwiliang, Kabupaten Bogor

\begin{tabular}{|c|c|c|c|c|c|c|c|c|c|}
\hline \multirow[t]{2}{*}{ No } & \multirow[t]{2}{*}{ Sub variabel } & \multirow[t]{2}{*}{ Kategori } & \multicolumn{2}{|c|}{$\begin{array}{c}\text { Desa } \\
\text { Barengkok }\end{array}$} & \multicolumn{2}{|c|}{$\begin{array}{c}\text { Desa } \\
\text { Leuwimekar } \\
\text { Mann } \\
\text { Whitney }\end{array}$} & \multicolumn{2}{|c|}{ Total } & \multirow{2}{*}{$\begin{array}{c}\text { Uji beda } \\
\text { Signifikansi }\end{array}$} \\
\hline & & & $\mathbf{n}$ & $\%$ & $\mathbf{n}$ & $\%$ & n & $\%$ & \\
\hline \multirow[t]{4}{*}{1} & Umur & Muda & 14 & 35,0 & 8 & 20,0 & 22 & 27,5 & 0,809 \\
\hline & \multirow{3}{*}{ (tahun) } & Dewasa & 3 & 7,5 & 17 & 42,5 & 20 & 25,0 & \\
\hline & & Tua & 23 & 57,5 & 15 & 37,5 & 38 & 47,5 & \\
\hline & & Total & 40 & 100,0 & 40 & 100,0 & 80 & 100,0 & \\
\hline \multirow[t]{4}{*}{2} & Pendidikan formal & Rendah & 18 & 45,5 & 25 & 62,5 & 43 & 53,75 & \\
\hline & \multirow{3}{*}{ (tahun) } & Sedang & 19 & 47,5 & 15 & 37,5 & 34 & 42,50 & 0,074 \\
\hline & & Tinggi & 3 & 7,5 & 0 & 0 & 3 & 3,75 & \\
\hline & & Total & 40 & 100,0 & 40 & 100,0 & 80 & 100,0 & \\
\hline \multirow[t]{4}{*}{3} & \multirow{4}{*}{$\begin{array}{l}\text { Pendidikan nonformal } \\
\text { (kali) }\end{array}$} & Rendah & 0 & 0 & 0 & 0 & 0 & 0 & \\
\hline & & Sedang & 14 & 35 & 22 & 55 & 36 & 45 & 0,074 \\
\hline & & Tinggi & 26 & 65 & 18 & 45 & 44 & 55 & \\
\hline & & Total & 40 & 100 & 40 & 100 & 80 & 100 & \\
\hline \multirow[t]{4}{*}{4} & \multirow{2}{*}{$\begin{array}{l}\text { Pengalaman berusaha } \\
\text { tani }\end{array}$} & Rendah & 0 & 0 & 0 & 0 & 0 & 0 & \\
\hline & & Sedang & 18 & 45 & 10 & 25 & 28 & 35 & 0,062 \\
\hline & \multirow{2}{*}{ (tahun) } & Tinggi & 22 & 55 & 30 & 75 & 52 & 65 & \\
\hline & & Total & 40 & 100 & 40 & 100 & 80 & 100 & \\
\hline \multirow[t]{4}{*}{5} & Penguasaan lahan & Sempit & 21 & 52,0 & 18 & 45 & 39 & 48,75 & \\
\hline & \multirow{3}{*}{ (ha) } & Sedang & 6 & 7,5 & 12 & 30 & 18 & 22,50 & \\
\hline & & Luas & 13 & 40,0 & 10 & 25 & 23 & 28,75 & 0,900 \\
\hline & & Total & 40 & 100,0 & 40 & 100 & 80 & 100,00 & \\
\hline
\end{tabular}

Keterangan: Nilai signifikansi Mann Whitney $\geq 0,05$ tidak berbeda nyata 
dari 5 tahun yaitu hanya sampai kelas 1, kelas 2, kelas 4 dan kelas 5 SD. Petani yang berpendidikan SMP sebanyak 22 petani yang ditempuh selama 9 tahun dan SMA sebanyak 14 petani yang ditempuh selama 12 tahun. Dari 80 responden hanya sekitar 3 orang $(3,75 \%)$ yang berpendidikan formal DiplomaSarjana.

Tidak terdapat perbedaan karakteristik internal di dua desa penelitian. Umur petani responden di dua desa penelitian rata-rata berumur tua yaitu 50 tahun. Pendidikan formal di dua desa penelitian pendidikan formal tergolong rendah. Pendidikan non formal di dua desa penelitian termasuk dalam kategori tinggi yaitu sebanyak 2 kali mengikuti pelatihan/kursus PTT. Pengalaman berusahatani rata-rata sudah 17 tahun dan mayoritas petani memiliki luas lahan sempit yaitu $\leq 0,25$ ha.

\section{Karakteristik Eksternal Petani}

Karakteristik eksternal petani yang diamati dalam penelitian ini adalah terdiri dari ketersediaan informasi teknologi PTT dan ketersediaan sarana produksi teknologi PTT. Ketersediaan informasi termasuk kategori tinggi (tersedia). Sumber informasi yang paling dominan adalah berasal dari penyuluh dan ketua kelompok tani, sedangkan media informasi yang digunakan petani adalah dari media televisi, Koran (sinar tani), brosur/leaflet. Kondisi ketersediaan sarana produksi di lokasi penelitian cukup baik. Ketersediaan peralatan sudah cukup baik, karena terlihat dari Desa Barengkok dan Desa Leuwimekar mempunyai empat traktor, dan tiga penggilingan padi. Mayoritas lokasi garapan petani dilalui melalui jalan desa, sehingga memudahkan sarana transportasi menuju lahan garapan. Alat transportasi yang digunakan untuk berusaha tani padi yaitu dengan memakai becak, gerobak, sepeda, sepeda motor dan sampai mobil, bahkan ada juga yang tidak menggunakan alat transportasi yaitu dengan dipikul saja.

Hasil uji beda Mann Whitneymenunjukkan bahwa tingkat ketersediaan saprodi terdapat perbedaan antara responden pada Desa Barengkok dan Desa Leuwimekar. Petani di Desa Barengkok lebih mudah mendapatkan sarana produksi (bibit, pupuk, obat-obatan) dalam mendukung usahatani padi karena banyak tersedia kios saprodi, penggilingan padi, dan pengairan dibandingkan

\section{dengan Desa Leuwimekar.}

\section{Pengetahuan tentang Inovasi PTT}

Sebesar 50\%, pengetahuan petani tentang teknologi inovasi varietas unggul tergolong tinggi (skor 2,35-3,00). artinya sebagian besar petani sudah mengetahui varietas yang unggul sesuai anjuran. Varietas yang digunakan merupakan varietas yang berlabel dan dikeluarkan resmi oleh pemerintah. Jenis varietas yang digunakan: Ciherang, IR 64, IR Super, Inpari, Cibogo, Hibrida, Mekongga. Sebesar 54\% pengetahuan petani tentang teknologi sistem tanam tergolong tinggi (skor 2,35-3,00). Sistem tanam yang sesuai anjuran yaitu dengan sistem legowo yang terdiri dari Legowo 2:1 $(40 \mathrm{~cm} \times 20$ $\mathrm{cm} \times 10 \mathrm{~cm})$, dan legowo 4:1 (20 cm x $10 \mathrm{~cm}$ x 40 $\mathrm{cm})$.

Pengetahuan petani tentang bahan organik termasuk pada ketegori tinggi yaitu sebesar $76 \%$, artinya bahwa petani mempunyai pengetahuan tentang bahan organik. Hal ini terlihat bahwa sebagian besar petani sudah mengurangi penggunaan pupuk kimia dan mulai menerapkan pupuk organik yang berasal dari kotoran hewan (bokhasi), dan pupuk kompos untuk tanaman padi. Sebesar 57\% pengetahuan petani tentang pengairan tergolong tinggi (skor 2,35-3,00). sudah tahu pengairan tanaman padi yang baik dan sesuai anjuran. Sebanyak $62 \%$ petani mengetahui teknologi pengendalian gulma, hama dan penyakit tergolong tinggi (skor 2,35-3,00), artinya bahwa petani sudah cukup tahu cara pengendalian gulma, hama dan penyakit yang tepat dan benar. Seperti pada saat tanaman padi diserang hama wereng coklat, petani sudah bisa mengendalikan hama tersebut yaitu dengan menyemprot dengan pupuk cair, atau dengan obat yang disarankan penyuluh setempat.

Sebesar $60 \%$ dari para petani memiliki pengetahuan tentang inovasi penanganan panen dan pasca panen yang tergolong tinggi (skor 2,353,00 ), artinya petani sudah tahu bagaimana cara penanganan panen dan pasca panen yang tepat dan baik. Apabila dilihat dari segi tenaga kerja dan alat yang digunakan sudah tersedia dengan baik. Pemotongan padi dilakukan sekelompok pemanen profesional yang terdiri dari 10-15 orang. Alat yang digunakan seperti mesin giling ada 5 buah, sabit 1020 buah, dan angkutan terdiri dari gerobak, motor dan sepeda tetapi ada juga dengan dipikul. Hasil 
Tabel 2 Karakteristik eksternal petani di Kecamatan Leuwiliang, Kabupaten Bogor

\begin{tabular}{|c|c|c|c|c|c|c|c|c|c|}
\hline \multirow[t]{2}{*}{ No } & \multirow[t]{2}{*}{ Sub variabel } & \multirow[t]{2}{*}{ Kategori } & \multicolumn{2}{|c|}{$\begin{array}{c}\text { Desa } \\
\text { Barengkok }\end{array}$} & \multicolumn{2}{|c|}{$\begin{array}{c}\text { Desa } \\
\text { Leuwimekar }\end{array}$} & \multicolumn{2}{|c|}{ Total } & \multirow{2}{*}{$\begin{array}{c}\text { Uji beda } \\
\text { Mann } \\
\text { Whidan tney } \\
\text { Signifikansi }\end{array}$} \\
\hline & & & n & $\%$ & n & $\%$ & n & $\%$ & \\
\hline \multirow[t]{4}{*}{1} & \multirow{4}{*}{$\begin{array}{l}\text { Ketersediaan } \\
\text { Informasi }\end{array}$} & Rendah & 0 & 0 & 0 & 0 & 0 & 0 & \multirow{4}{*}{0,693} \\
\hline & & Sedang & 11 & 27,5 & 13 & 32,5 & 24 & 30 & \\
\hline & & Tinggi & 29 & 72,5 & 27 & 67,5 & 56 & 70 & \\
\hline & & Total & 40 & 100,0 & 40 & 100,0 & 80 & 100 & \\
\hline \multirow[t]{4}{*}{2} & \multirow{4}{*}{$\begin{array}{l}\text { Ketersediaan } \\
\text { Saprodi }\end{array}$} & Rendah & 0 & 0 & 0 & 0 & 0 & 0 & \multirow{4}{*}{$0,020^{*}$} \\
\hline & & Sedang & 12 & 30 & 22 & 55 & 34 & 42,5 & \\
\hline & & Tinggi & 28 & 70 & 18 & 45 & 46 & 57,5 & \\
\hline & & & 40 & 100 & 40 & 100 & 80 & 100,0 & \\
\hline
\end{tabular}

Keterangan: $\quad$ Nilai signifikansi Mann Whitney $\leq 0,05$ berbeda nyata Nilai signifikansi Mann Whitney $\geq 0,05$ tidak berbeda nyata

uji beda Mann Whitney menunjukkan pengetahuan petani terhadap inovasi PTT terdapat perbedaan antara petani responden pada Desa Barengkok dan Desa Leuwimekar. Pengetahuan petani di Desa Barengkok tentang penggunaan bahan organik sudah tergolong baik. Hal ini dikarenakan bahan organik berasal dari jerami padi kotoran ternak sapi, kerbau dan dari sisa tanaman. Pengetahuan petani di Desa Barengkok cukup tahu mengenai sistem pengairan berselang, pengendalian gulma, HPT dan penanganan panen dan pascapanen hal ini dikarenakan responden sudah berpengalaman dalam melakukan pengaturan air dan sudah mendapatkan pelatihan seperti SL-PTT dan SLPHT dibandingkan dengan petani di Desa Leuwimekar.

\section{Persepsi Petani Terhadap Inovasi PTT}

Persepsi petani terhadap inovasi PTT (varietas unggul, system tanam, bahan organik, pengairan berselang, pengendalian gulma, hama dan penyakit, serta pengananan panen dan pascapanen) didasarkan pada karakteristik inovasi, yaitu: bagaimana tingkat keuntungannya, tingkat kesesuaian, tingkat kerumitan, dapat dicobakan pada tingkatan skala, dan dapat diperlihatkan hasil komponen PTT. Persepsi petani terhadap varietas unggul tergolong sangat tinggi $(3,26-4,00)$, artinya petani sudah memiliki pemahaman terhadap nilai keunggulan varietas unggul lebih baik, hal ini tampak bahwa penggunaan varietas unggul dapat lebih menguntungkan bila dibandingkan dengan varietas lokal/biasa, sesuai dengan kebutuhan petani, varietas unggul mudah diterapkan baik dalam skala kecil maupun skala besar, dan dapat dicobakan dalam skala luasan yang lebih kecil, serta dapat dilihat perbedaan hasilnya dengan varietas biasa/ lokal.

Persepsi petani terhadap sistem tanam tergolong sangat tinggi (3,26-4,00). Sistem tanam dengan cara legowo dapat memberikan banyak keuntungan dari pada sistem tanam tanpa jajar. Selain pertanaman rapi, juga lebih efisien dalam penggunaan pupuk dan dalam melakukan pengendalian gulma, hama dan penyakit. Selain berusahatani padi, petani juga mengusahakan ternak, seperti: ayam, itik, kerbau, kambing, dan domba, sehingga pupuk organik cukup tersedia oleh mereka sendiri.

Persepsi petani terhadap sistem penga-iran berselang termasuk kategori sangat tinggi (3,264,00). Artinya bahwa petani memiliki penilaian yang baik terhadap inovasi PTT padi. Hal ini juga di dukung oleh ketersediaan air untuk mengairi lahan sawah mereka karena terdapat sungai di desa penelitian. Petani menyatakan keuntungan yang didapat dari tanaman padi yang dilakukan dengan pengaturan air secara baik akan lebih banyak hasil dari pada tanaman yang tidak pernah dilakukan pengaturan air. Sesuai dengan keadaan setempat, 
Tabel 3 Persepsi Petani di Kecamatan Leuwiliang, Kabupaten Bogor terhadap Inovasi PTT

\begin{tabular}{|c|c|c|c|c|}
\hline No & Variabel & $\begin{array}{l}\text { Desa Barengkok } \\
\qquad(\mathrm{n}=\mathbf{4 0})\end{array}$ & $\begin{array}{l}\text { Desa Leuwimekar } \\
\qquad(\mathrm{n}=\mathbf{4 0})\end{array}$ & $\begin{array}{c}\text { Ujibeda Mann } \\
\text { Whitney } \\
\text { signifikansi }\end{array}$ \\
\hline 1 & Varietas unggul & 3,6 & 3,5 & $0,014^{*}$ \\
\hline 2 & System tanam & 3,5 & 3,3 & 0,08 \\
\hline 3 & Bahan organik & 3,8 & 3,5 & $0,002 *$ \\
\hline 4 & Pengairan berselang & 3,4 & 3,4 & 0,988 \\
\hline 5 & $\begin{array}{l}\text { Pengendalian gulma, } \\
\text { hama dan penyakit }\end{array}$ & 3,4 & 3,4 & 0,711 \\
\hline 6 & $\begin{array}{l}\text { Penanganana panen dan } \\
\text { pasca panen. }\end{array}$ & 3,2 & 3,2 & 0,609 \\
\hline
\end{tabular}

\section{Keterangan:}

Persepsi inovasi PTT : 3,5 dan3,4

$\begin{array}{lllll}\text { Persepsi } & : \text { Rendah } & : 1-1,75 ; & \text { Tinggi } & : 2,51-3,25 \\ & \text { Sedang } & : 1,76-2,50 ; & \text { Sangat Tinggi } & : 3,26-4,00\end{array}$

Nilai signifikansi Mann Whitney $\leq 0,05$ berbeda nyata

tidak rumit untuk mengatur kegunaan air sesuai dengan kebutuhan petani, dan pengaturan air yang sesuai memberikan dampak positif terhadap hasil produksi.

Hasil penelitian menunjukkan persepsi petani terhadap pengendalian gulma, hama, dan penyakit termasuk kategori di Desa penelitian sangat tinggi (3,26-4,00), artinya pemahaman petani terhadap pengendalian gulma, hama, dan penyakit sudah baik, ini berarti sebagian karakteristik dari inovasi tersebut dapat dipahami dengan benar. Tindakan pengendalian ini dilakukan dengan sempurna akan lebih menguntungkan, dan tidak bertentangan dengan kebiasaan secara pribadi maupun masyarakat setempat. Kerumitan dalam pelaksanaan kegiatan ini menurut petani sangat relatif karena tergantung dari aspek yang lain. Persepsi petani terhadap penanganan panen dan pasca panen termasuk kategori tinggi $(2,51-3,25)$. Di dua desa penelitian tingkat kesesuaian teknologi bisa diterima oleh petani, karena persepsi petani sama dengan konsep kesesuaian yang ditawarkan oleh teknologi PTT.

Hasil uji beda Mann Whitneymenunjukkan bahwa varietas unggul dan bahan organik terdapat perbedaan antara responden pada Desa Barengkok dan Desa Leuwimekar. Petani di wilayah Desa Barengkok sudah menggunakan varietas unggul yang sesuai anjuran seperti Ciherang, IR 64, IR Super, Inpari, Cibogo, Hibrida dan Mekongga, sedangkan di Desa Leuwimekar walaupun persepsi petani baik tentang varietas unggul namun masih ada petani yang menggunakan varietas lokal karena harganya lebih murah dan terbiasa menggunakan bibit dari hasil padi sebelumnya. Persepsi petani Desa Barengkok tentang penggunaan bahan organik sudah tergolong baik. Selain malakukan usaha tani, responden juga bermata pencaharian sebagai peternak sapi dan kerbau. Oleh karena itu, bahan organik cukup tersedia yaitu baik dari kotoran ternak maupun dari sisa tanaman seperti jerami padi dan dibandingkan dengan Desa Leuwimekar yang tidak bermata pencaharian sebagai peternak.

\section{Tingkat Adopsi Inovasi PTT}

Hasil penelitian menunjukkan bahwa adopsi petani terhadap inovasi teknologi komponen PTT termasuk kategori tinggi yaitu skor 2,353,00. Adopsi di desa Barengkok dengan skor 2,5, dan di desa Leuwimekar dengan skor 2,6 artinya bahwa mayoritas petani sudah menerapkan inovasi PTT dengan baik (Tabel 4). Varietas unggul yang dianjurkan oleh pemerintah adalah terdiri dari Ciherang, IR-64, Mekongga, Cimelati, Cibogo, Cisadane, Situ Patenggang, Cigeulis, Ciliwung, Mem-bramo, Sintanur, Jati luhur, Fatmawati, dan Situbagendit. Sistem adopsi inovasi teknologi terhadap varietas unggul mayoritas sudah sesuai dengan konsep PTT, varietas yang digunakan petani yaitu Ciherang, IR Super, Inpari, Cibogo, 
Tabel 4 Tingkat Adopsi Inovasi PTT di Kecamatan Leuwiliang, Kabupaten Bogor Tahun 2014

\begin{tabular}{|c|c|c|c|c|c|}
\hline \multirow{2}{*}{ Kategori } & \multicolumn{2}{|c|}{$\begin{array}{c}\text { Desa } \\
\text { Barengkok }\end{array}$} & \multicolumn{2}{|c|}{ Desa Leuwimekar } & \multirow{2}{*}{$\begin{array}{c}\text { Uji beda Mann Whit- } \\
\text { ney } \\
\text { Signifikansi }\end{array}$} \\
\hline & n & $\begin{array}{l}\text { Tingkat } \\
\text { adopsi }\end{array}$ & $\mathbf{n}$ & $\begin{array}{l}\text { Tingkat } \\
\text { adopsi }\end{array}$ & \\
\hline Rendah & 3 & & 0 & & \\
\hline Sedang & 14 & 2,6 & 28 & 2,5 & $0,007 *$ \\
\hline Tinggi & 23 & & 12 & & \\
\hline Total & 40 & & 40 & & \\
\hline \multicolumn{6}{|l|}{ Keterangan: } \\
\hline Tingkat Adopsi & $\begin{array}{c}=\text { Rendah } \\
\text { Sedang } \\
\text { Tinggi }\end{array}$ & $\begin{array}{l}: 1, \\
: 1, \\
: 2,\end{array}$ & & & \\
\hline
\end{tabular}

Hibrida dan Mekongga. Tetapi petani responden juga berharap untuk kedepannya ada perkembangan varietas yang lebih baik dari yang sudah ada. Hal ini sesuai dengan penyataan salah seorang petani $(\mathrm{H}, 45$ tahun):

\section{"Varietas yang kami gunakan sudah berlabel dari pemerintah, tapi mah tuk ke depannya kami pengen ada benih yang lebih bagus lagi dan lebih bisa tahan terhadap hama dan penyakit, yang lama masih belum tahan 100\% terhadap hama penyakit tanaman padi"}

Sistem tanam yang dianjurkan dalam pengelolaan tanaman terpadu adalah sistem tanam dengan menggunakan barisan secara legowo. Adopsi petani terhadap teknologi sistem tanam meliputi sistem Legowo 2:1 (40 cm x $20 \mathrm{~cm} \times 10 \mathrm{~cm})$, dan Legowo 4:1 (20 cm x $10 \mathrm{~cm}$ x $40 \mathrm{~cm})$. Penggunaan terhadap teknologi bahan organik seperti bokhasi dan kompos sudah mulai diterapkan oleh petani karena dapat memberikan keuntungan yang lebih baik dan tidak merusak lingkungan. Hal ini Seperti yang dikemukakan oleh bapak S (petani, 73 tahun):

\footnotetext{
"Kalau pupuk alami kan bisa menyuburkan tanah dan menyehatkan tanaman padi dibandingkan dengan pupuk kimia, untuk itu saya sudah mengurangi pakai pupuk
}

\section{Kimia dan hampir 5 tahun rutin pakai pupuk kompos dan bok hasi untuk tanaman padi dan hasilnya juga meningkat dari sebelumnyä'.}

Pengairan berselang adalah pengaturan kondisi lahan dalam kondisi kering dan tergenang secara bergantian, dengan tujuan: menghemat ketersediaan air, memberi kesempatan akar tanaman untuk mendapatkan udara, mencegah adanya penimbunan asam organik, memudahkan pemeliharaan, dan menyeragamkan proses pemasakan gabah. Sebesar 62,5\% (Desa Barengkok) dan $50 \%$ (Desa Leuwimekar) petani sudah mengadopsi/ melakukan pengaturan air tergolong tinggi yaitu (skor 2,35-3,00) (Humphreys et al., 2006), menyatakan bahwa efisiensi penggunaan air sawah secara terpadu dapat memaksimalkan keuntungan ekonomi dan menyeimbangkan ekosistem lingkungan dengan kebutuhan irigasi pertanian.

Di dua desa penelitian petani sudah mengadopsi teknologi pengendalian gulma, hama dan penyakit pada tanaman padi dengan cukup baik artinya bahwa petani mengerti dalam mengendalikan gulma dan hama penyakit yang menyerang tanaman padi sesuai dengan anjuran PTT. Hasil penelitian Bastiaans et al. (2008), menyatakan bahwa penerapan pengelolaan gulma secara terpadu seperti pengolahan tanah yang sempurna, waktu tanam yang serentak, dan menjaga sanitasi lahan dapat 
Tabel 5 Pengaruh faktor internal dan ekternal terhadap adopsi inovasi PTT padi

\begin{tabular}{cll}
\hline No & Variabel & b \\
\hline 1 & Umur & $0,344^{* *}$ \\
2 & Pendidikan formal & 0,195 \\
3 & Pendidikan non formal & 0,073 \\
4 & Pengalaman berusaha tani & $0,853^{* *}$ \\
5 & Penguasaan lahan & $0,254^{* *}$ \\
6 & Ketersediaan informasi teknologi PTT & $0,123^{* *}$ \\
7 & Ketersediaan saprodi & $-0,032$ \\
\hline
\end{tabular}

Keterangan: $\quad * *$ Signifikan pada taraf $5 \%$

b: koefisien Regresi

terhindar dari serangan hama dan penyakit dan resiko kegagalan hasil panen tanaman padi.

Dalam penanganan panen dan pasca panen harus dilakukan secara tepat untuk mengurangi kehilangan hasil dan meningkatkan kualitas gabah. Hasil penelitian Jabir (2012), menyatakan bahwa pengananan panen dan pascapanen secara terpadu dapat meningkatkan keuntungan produktivitas dan kualitas produk. Adopsi inovasi terhadap penanganan panen berjalan baik yaitu dilakukan oleh kelompok pemanen profesional dan peralatan yang digunakan untuk pasca panen cukup tersedia.

\section{Faktor-faktor yang Berpengaruh terhadap Tingkat Adopsi Inovasi PTT Padi}

Hasil uji regresi menunjukkan nilai R2 sebesar $34,1 \%$, artinya keragaman yang dapat dijelaskan oleh model sebesar $34,1 \%$, sisanya $65,9 \%$ dijelaskan oleh faktor lain di luar model. Uji F menunjukkan $p$-value $0,000<0,05$, artinya model telah layak digunakan. Karakteristik internal petani yang diteliti terdiri dari: umur, pendidikan formal, pendikan non formal, pengalaman berusha tani dan penguasaan lahan. Karakteristik eksternal petani yang diteliti terdiri dari: ketersediaan informasi teknologi PTT dan ketersediaan saprodi (Tabel 5). Umur, pengalaman berusahatani, penguasaan lahan dan ketersediaan informasi berpengaruh nyata terhadap tingkat adopsi inovasi PTT padi. Semakin tua umur petani maka semakin matang dalam berpikir dan mengembangkan usahatani padinya dan tentunya akan mudah menerima suatu inovasi yang layak digunakan untuk untuk mereka terapkan. Berdasarkan penggolongan umur BPS, sebagian besar petani respoden tergolong dalam usia produktif yaitu antara 15 tahun sampai dengan 64 tahun. Petani yang berusia produktif memiliki kemampuan bekerja dan berfikir yang lebih tinggi dibanding dengan tidak produktif. Pernyataan ini sesuai dengan penelitian Riyadi (2003) bahwa umur yang matang sangat menentukan kemampuan dan kemauan petani untuk menerapkan teknologi padi sawah.

Pengalaman berusaha tani dan penguasaan lahan berpengaruh nyata terhadap tingkat adopsi inovasi PTT padi. Semakin banyak pengalaman maka semakin baik tingkat adopsi terhadap inovasi tersebut. Hal ini sejalan dengan hasil penelitian Roswida (2003) bahwa lama bertani berpengaruh dengan pengambilan keputusan dalam memilih inovasi pertanian. Petani yang memiliki pangalaman yang baik mampu berfikir lebih maju dalam mengembangkan usaha tani dengan mencari berbagai teknologi yang cocok dan sesuai untuk usaha taninya dan mencari penyelesaian/solusi terhadap masalah yang dihadapi. Hal ini sesuai dengan pernyataan salah seorang petani (M, 48 tahun):

"Saya bersyukur Neng, karena dengan
datangnya inovasi PTT ini dapat memberi
hasil produksi padi yang lebih baik dari
yang ada sebelumnya, Alhamdulillah jadi
tambah senang bertani."

Penguasaan lahan berpengaruh nyata dengan tingkat adopsi inovasi PTT padi. Artinya bahwa semakin luas lahan yang dikuasai petani akan semakin baik tingkat adopsi terhadap pengelolaan usahatani padi secara terpadu. Hasil penelitian Fachrista et al. (2013), menunjukkan bahwa luas 
Tabel 6 Pengaruh Faktor Pengetahuan dan Persepsi terhadap Tingkat Adopsi Inovasi PTT

\begin{tabular}{|c|c|c|c|}
\hline No & Variabel & $\begin{array}{c}\text { Pengetahuan } \\
\text { b } \\
\end{array}$ & $\begin{array}{c}\text { Persepsi } \\
\text { b } \\
\end{array}$ \\
\hline 1 & Varietas Unggul & 0,917 & $0,034 * *$ \\
\hline 2 & Sistem Tanam & $0,000 * *$ & 0,378 \\
\hline 3 & Bahan Organik & $0,001 * *$ & 0,423 \\
\hline 4 & Pengairan berselang & 0,269 & 0,142 \\
\hline 5 & Pengendalian gulma dan HPT & 0,618 & 0,870 \\
\hline 6 & Penanganan panen dan pascapanen & $0,000^{* *}$ & 0,812 \\
\hline
\end{tabular}

Keterangan: $\quad * *$ Signifikan pada taraf $5 \%$

b : koefisien Regresi

lahan mempengaruhi adopsi inovasi PTT. Berkaitan dengan kegiatan percobaan pertanian, tentunya petani memerlukan luasan lahan yang cukup, sehingga mereka dapat dengan leluasa mengamati atau mencoba inovasi dengan skala luasan yang lebih kecil tanpa mempengaruhi usahatani secara luas. Hal ini akan mendukung dalam meningkatkan pengetahuan petani terhadap pemahaman suatu inovasi.

Ketersediaan informasi berpengaruh nyata terhadap tingkat adopsi inovasi PTT padi. Artinya semakin banyak akses informasi yang tersedia untuk petani maka semakin baik adopsi terhadap inovasi sistem PTT padi. Keberadaan informasi sangat dibutuhkan oleh petani dalam rangka menambah pengetahuan serta keterampilannya guna meningkatkan sistem usahatani yang lebih baik. Pengetahuan dan persepsi petani terhadap inovasi PTT yang diteliti adalah terdiri dari komponen varietas unggul, sistem tanam, penggunaan bahanbahan organik, pengairan berselang, pengendalian gulma, hama dan penyakit, penanganan panen dan pascapanen.

Pengetahuan petani terdapat pengaruh positif terhadap tingkat adopsi inovasi PTT padi. Artinya semakin baik pengetahuan petani terhadap penerapan inovasi PTT padi maka semakin baik tingkat adopsi dan dapat mempengaruhi sistem pengelolaan tanaman padi yang lebih baik. Pengetahuan petani yang berpengaruh terhadap tingkat inovasi PTT adalah sistem tanam, bahan organik, dan penanganan panen dan pasca panen. Petani lebih mengerti tentang teknologi inovasi PTT yaitu sistem tanam yang diterapkan yaitu dengan legowo (4:1 dan 2:1), bahan yang digunakan berasal dari bahan-bahan organik (kompos dan bokhasi), serta penanganan panen dan pasca panen dengan tepat. Hal ini terbukti bahwa pengetahuan yang baik dapat berpengaruh terhadap penerimaan inovasi PTT padi.

Hasil penelitian Samboh (2013), menyatakan bahwa pengetahuan mempunyai hubungan sangat signifikan dengan tingkat adopsi inovasi. Hal ini sejalan dengan hasil penelitian Mariano et al. (2012) menunjukkan bahwa tingkat pengetahuan petani dalam penggunaan benih bersertifikat, pengaturan air/irigasi, kepemilikan mesin berdampak positif terhadap adopsi teknologi pengelolaan tanaman terpadu. Penelitian oleh Chowdhury and Prabuddha (2010), menunjukkan bahwa indeks pengetahuan petani terhadap teknik Pengendalian hama penyakit (PHT) berkorelasi positif dengan tingkat adopsi inovasi.

Persepsi petani terdapat pengaruh nyata terhadap tingkat adopsi inovasi PTT padi. Persepsi seseorang akan menentukan tingkat pengambilan keputusan terhadap inovasi (Susanto, 1977). Komponen inovasi PTT yang berpengaruh adalah pada teknologi varietas unggul. Ini berarti bahwa hubungan persepsi petani dalam penguasaan teknologi varietas unggul terhadap tingkat penerapannya dapat dianggap baik. Petani menganggap bahwa inovasi PTT padi layak diterapkan dan inovasi PTT terbukti dapat meningkatkan hasil produksi dari dari 5 ton/ ha menjadi 8 ton/ha. Berdasarkan pernyataan, jelas bahwa inovasi pengelolaan tanaman terpadu pada tanaman padi dapat membantu petani dalam mengembangkan usahatani ke depannya menjadi lebih baik.

\section{Kesimpulan}

Berdasarkan hasil penelitian di atas maka dapat disimpulkan bahwa tingkat adopsi inovasi 
Pengelolaan Tanaman Terpadu (PTT) padi sawah di Kecamatan Leuwiliang, Kabupaten Bogor termasuk kategori tinggi, artinya bahwa inovasi PTT diterima dengan baik oleh petani padi. Persepsi petani terhadap komponen teknologi inovasi PTT padi di Kecamatan Leuwiliang Kabupaten Bogor termasuk dalam kategori sangat tinggi. Faktor-faktor yang mempengaruhi tingkat adopsi inovasi PTT padi di Kecamatan Leuwiliang, Kabupaten Bogor adalah umur, pengalaman berusahatani, penguasaan lahan, ketersediaan informasi teknologi PTT, pengetahuan petani terhadap inovasi PTT dan persepsi petani terhadap inovasi PTT padi.

Umur, pengalaman berusahatani, penguasaan lahan dan ketersediaan informasi berpengaruh nyata terhadap tingkat adopsi inovasi PTT padi. Semakin tua umur petani maka semakin matang dalam berpikir dan mengembangkan usahatani padinya dan tentunya akan mudah menerima suatu inovasi yang layak digunakan untuk untuk mereka terapkan. Berdasarkan penggolongan umur BPS, sebagian besar petani respoden tergolong dalam usia produktif yaitu antara 15 tahun sampai dengan 64 tahun. Petani yang berusia produktif memiliki kemampuan bekerja dan berfikir yang lebih tinggi dibanding dengan tidak produktif.

Pengalaman berusaha tani dan penguasaan lahan berpengaruh nyata terhadap tingkat adopsi inovasi PTT padi. Semakin banyak pengalaman maka semakin baik tingkat adopsi terhadap inovasi tersebut. Petani yang memiliki pangalaman yang baik mampu berfikir lebih maju dalam mengembangkan usaha tani dengan mencari berbagai teknologi yang cocok dan sesuai untuk usaha taninya dan mencari penyelesaian/solusi terhadap masalah yang dihadapi.

\section{Daftar Pustaka}

Asngari PS. 1984. "Perception of District Extention Directors and County Extention Agent Chairmen Regarding the Roles and Functions of Texas Agricultural Extention Service, USA.” Bogor (ID): Media Peternakan.

Balai Penelitian Tanaman Padi. 2003. Pusat Penelitian dan Pengembangan Tanaman Pangan dan Balai Penelitian Tanaman Padi. Balai Besar Penelitian Tanaman Padi (BB Padi). [Internet]. [dapat diunduh dari: http//www.bbpadi.litbang. Deptan.go.id].
Badan Pengkajian Teknologi Pertanian. 2012. Pusat Penelitian Teknologi Pertanian Padi Sawah Bogor. Badan Pengkajian Teknologi Pertanian Kabupaten Bogor. [Internet]. [dapat diunduh dari: http//www.Jabar.litbang. pertanian.go.id].

Bastians P, Baumann. 2008. "Focus on Ecological Weed Management: What is Hindering Adoption?.” Journal crop and Weed Ecological Research. [Internet]. [dapat diunduh dari: http// www.search.epnet.com].

Chowdhury S, Prabuddha R. 2010. "Knowledge Level and Adoption of the Integrated Pest Management (IPM) Techniques: a Study Among the Vegetable Growers of Katwa subDivision, Bardhaman District." Indian Journal of Agricultural Research. [Internet]. [dapat diunduh dari: http//www.search.epnet.com].

Dinas Pertanian Jabar. 2013. Petunjuk Pelaksanaan Sekolah Lapang .

Pengelolaan Tanaman Terpadu (SL-PTT) Padi dan Jagung. [Internet]. [dapat diunduh dari: $\mathrm{http} / /$ www.Pednis_SLPTT2013.pdf].

Haryani D. 2009. "Analisis Efisiensi Usahatani Padi Sawah pada Program Pengelolaan dan Sumberdaya Terpadu di Kabupaten Serang Provinsi Banten. [tesis]. Bogor (ID): Sekolah Pascasarjana, Institut Pertanian Bogor."

Fachrista IA, Hendayana R, Risfaheri. (2013). "Faktor Sosial Ekonomi Penentu Adopsi Pengelolaan Tanaman Terpadu (PTT) Padi Sawah di Bangka Belitung." Jurnal Informatika Pertanian. [Internet]. [dapat diunduh dari: http// www.litbang.pertanian.go.id].

Jabir A. 2012. "Factors Influencing Adoption of Postharvest Practices in Vegetables." International Journal of Vegetable Science. [Internet]. [dapat diunduh dari: http//www. search.epnet.com].

Jim MM, Renato V, Euan F. 2012. "Factors Influencing Farmers' Adoption of Modern Rice Technologies and Good Management Practices in the Philippines." Journal sciencedirect Agricultural Systems. [Internet]. [dapat diunduh dari: http//www.science direct.com].

Khan HL, Lacy B, Thompson, Brown B, Russell. 2006. "Integration of Approaches to Increasing Water use Efficiency in Rice-Based Systems in Southeast Australia." Journal Field Crops Research. [Internet]. [dapat diunduh dari: http// 
www. search.epnet.com].

Riyadi. 2003. "Hubungan antara Hasil Pelatihan dengan Tingkat Penerapan Padi Sawah di Kalimantan Timur." [tesis]. Bogor (ID): Sekolah Pascasarjana, Institut Pertanian Bogor.

Roswida R. 2003. Tahapan Proses Keputusan Adopsi Inovasi Pengendalian Hama dan Penyakit Tanaman dengan Agen hayati (Kasus petani sayur di kecamatan Banuhampu dan Sungai Puar kabupaten Agam Sumatera Barat. [tesis]. Bogor (ID): Institut Pertanian Bogor.

Samboh RD. 2013. “Adopsi Inovasi Program Sapta
Pesona Oleh Pengelola Hotel di Jakarta Timur." [tesis]. Bogor (ID): Sekolah Pascasarjana, Institut Pertanian Bogor.

Soekartawi. 1988. Prinsip Dasar Komunikasi Pertanian. Jakarta (ID): Indonesia University Press.

Susanto. 1977. Komunikasi Kontemporer. Jakarta (ID): Binacipta.

Slamet M. 2001. Paradigma penyuluhan pertanian dalam era otonomi daerah. [Internet]. [dapat diunduh dari: http://margonoipb.files.wordpress. com]. 